\title{
A Technique for Treatment of Overdrainage in Ventriculoperitoneal Shunt
}

Essossinam Kpélao ${ }^{1^{*}}$, Katanga Anthony Békéti ${ }^{1}$, Abdel Kader Moumouni ${ }^{1}$, Kodjo Mensah Hobli-Ahanogbé ${ }^{1}$, Agbéko Komlan Doléagbenou ${ }^{1}$, Komi Egu ${ }^{1}$, Thierry Alihonou ${ }^{2}$, Essosolim Hodabalo Bakondé ${ }^{\text {, }}$ Pilakimwé Egbohou ${ }^{3}$, Assang Dossim ${ }^{1}$

\footnotetext{
${ }^{1}$ Department of Neurosurgery, Sylvanus Olympio University Hospital, Lomé, Togo

${ }^{2}$ Department of Surgery University Hospital Center of Ouémé and Plateau, Benin

${ }^{3}$ Intensive Care Unit, Sylvanus Olympio University Hospital, Lomé, Togo

* Corresponding Author Address: Department of Neurosurgery, CHU Sylvanus Olympio. 08 BP : 8615, Lomé, Togo. E-mail: kpelas77@yahoo.fr.
}

Article Type: Case Series

Received: May 11, 2017, Last Revised: May 20, 2017, Accepted: May 25, 2017, Published: September 28, 2017

\section{Abstract}

Background and Importance: Overdrainage is a complication of ventriculoperitoneal shunt but adjustable valves and anti-siphon devices can prevent it. These very expensive valves are most often inaccessible, so that the majority of the valves available in Togo are fixed differential pressure valves. Although overdrainage is a widely-known issue, we aimed to introduce a new risk factor and the way we manage this complication.

Case Presentation: This case series study included all patients who had overdrainage or a high potential risk of overdrainage (hydranencephaly). Our technique consisted of partial ligation of the peritoneal catheter at the level of the thorax by non-resorbable wire while controlling the drainage rate at the slots. The goal was to transform this fixed differential pressure valve into a pressure-controlled and flow-regulated one. Patients were followed for 1, 3 and 6 months, postoperatively.

Conclusion: Hydranencephaly predisposes patients to overdrainage. The partial ligature of the catheter is an effective technique for treating or preventing overdrainage.

Keywords: Overdrainage; Ligation; Catheter

Please cite this paper as: Kpélao E, Békéti K.A, Moumouni A.K, Hobli-Ahanogbé K.M, Doléagbenou A.K, Egu K, et al. Iran J Neurosurg. 2017;3(2):58-62

Background and Importance

The ventriculoperitoneal shunt (VPS) is the most common treatment of hydrocephalus. This treatment has many complications including overdrainage which has been defined as the excessive evacuation of cerebrospinal fluid (CSF) from the ventricular system [1]. Overdrainage is mainly caused by a siphon effect during postural changes when the patient is in an upright position [2,3]. An estimated 10\% of patients with long-term shunts will experience symptoms of overdrainage [2]. Conventionally fixed differential pressure valves are not sufficiently equipped to prevent this complication, which has led to the development of adjustable valves and anti-siphon systems [4,5]. This technology has been made to attempt as far as possible to adapt the drainage pressure of the valve to the optimum pressure of the patient to avoid overdrainage [6-8]. These very expensive valves are most often inaccessible, so that majority of them available in Togo are fixed differential pressure valves. Therefore, some patients will be exposed to hypodrainage or overdrainage. Although overdrainage is a well-known phenomenon, we aimed at evoking a new factor favoring its occurrence and our management of this complication in this study.

\section{Case Presentation}

This is a case series study on patients admitted to neurosurgery department of a university hospital, Sylvanus Olympio in Lomé of Togo, over a period of 3 years (2014-2016). It included all patients who had overdrainage (clinical and radiological) after VPS and patients identified with 
potential high risk of overdrainage (hydranencephaly). Written informed consent was obtained from all participants included in the study.

Our technique to prevent or treat overdrainage consisted of partial ligation of the peritoneal catheter at the level of the thorax using silk suture 2/0 (Mersuture $\AA$ ), while controlling the drainage rate at the slots, before its introduction into the abdominal cavity (Figure 1). The nonabsorbable wire was tied to obtain an average flow of $1.5 \mathrm{ml}$ of CSF after 5 minutes at the distal tip using a graduated syringe. We used fixed differential pressure valves (medium and high). This procedure was done preventively during shunting, or curatively in case of overdrainage during a shunt revision. The goal was to transform this fixed differential pressure valve into a valve with both a pressure-controlled and flow-regulated valve. No other treatment was associated with this technique. The clinical evaluation method disappeared or remained signs of overdrainage. Patients were reviewed for 1 month, 3 months and then 6 months, postoperatively.

Thirteen patients were operated using this technique, 5 curatively and 8 preventively. The patients' age range was between 7 days and 10 years. Most of them were women $(n=8)$. The patients had congenital malformation hydrocephalus including 9 hydranencephalies (69.2\%). In 6 cases, hydrocephalus was associated with myelomeningocele. Twelve patients had the shunt at the atrium of the right lateral ventricle and one in the frontal horn. The average time for applying the technique was 15 minutes in preventive ligation during the realization of the VPS and 30 minutes if it was a curative treatment during the valve revision. The preoperative mean cranial perimeter was $56.3 \mathrm{~cm}$. Five patients had clinical signs over drainage: headache ( 2 cases), vomiting (3 cases), lethargy (3 cases), depression of the anterior fontanelle (3 cases), a tendency to craniosynostosis (3 cases), abdominal bloating (3 cases) and dyspnea (3 cases) (Figure 2). The delay in the appearance of signs of overdrainage varied from 4 days to 9 years after the shunt placement. Of these 5 patients treated curatively, 3 had hydranencephaly and 2 had hydrocephalus; 4 patients had a medium pressure valve. The CT scan revealed a chronic subdural hematoma (CSDH) in one patient and collapse of ventricles (Figure 3). Post-operative follow-up for patients treated with the intention to cure were favorable as the signs of overdrainage disappeared in all cases. For preventive approach, no overdrainage signs were observed, and these patients had an average cranial perimeter of $53.4 \mathrm{~cm}$ at 6 months.

\section{Discussion and Conclusion}

The hydrodynamic complications of ventriculo-peritoneal shunt can rise up to $40 \%$ according to the series [2,6,914]. Overdrainage is due to insufficient valve pressures and siphoning of CSF during postural changes [2,5,15-17]. The postural alterations, particularly shifting from supine to upright, induced a "sucking" effect of CSF [18]. Several other causes evoked such as female sex, age, height, and respiratory cycle but not proved [15,17,19-22]. Overdraining caused intracranial hypotension and collapse of ventricles, leading to subdural hematomas and craniosynostosis [3,23]. The flow of CSF into the abdominal cavity during overdrainage in the infants exceeds the capacities of resorption of the peritoneum, leading to abdominal distension and then dyspnea. The treatment and prevention of overdrainage is still a challenge, even if there are solutions and approaches by introducing several methods such as high-pressure valves, anti-siphon systems, and adjustable valves [4,11,24-26]. These different methods allow reducing the frequency but they have limitations $[6,7,27,28]$. The low availability and/or inaccessibility of these systems in our region, and difficulties faced in managing patients with overdrainage led us to adopt this technique of prevention and treatment. Indeed, we have recorded two cases of deaths in infants due to the complications of overdrainage and the difficulties of its management before this study. The management of hydranencephaly is still controversial. Some authors are abstinent; others choose surgery by defending fair arguments [29-35]. In our department, we prefer surgery. According to the physical law, the pressing forces which apply on a 
Treatment of Overdrainage in Ventriculoperitoneal Shunt

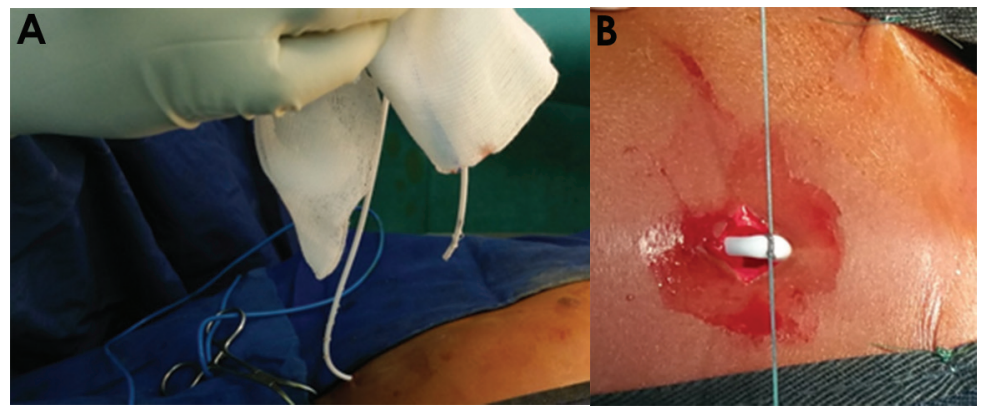

Figure 1. Illustration of the intraoperative Ligature of the Distal Catheter at the Level of the Thorax under Control of the Flow Rate of the LCS
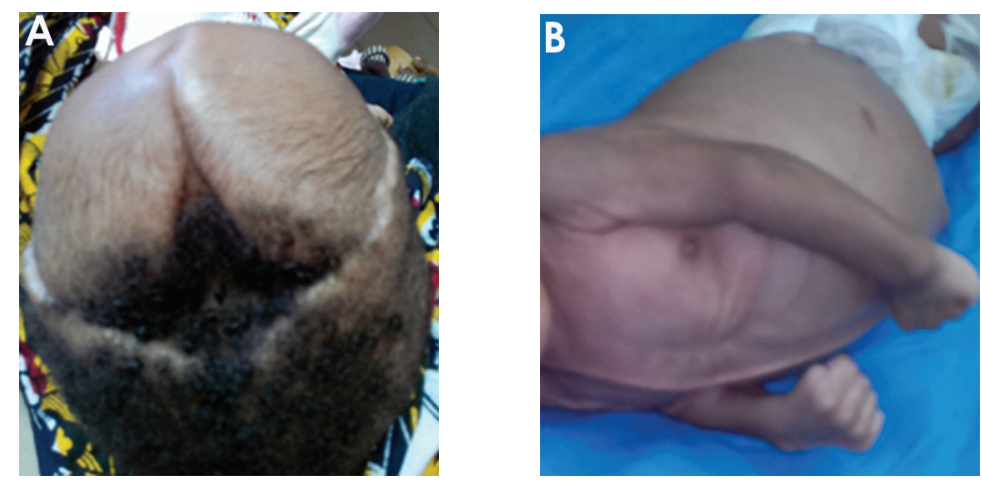

Figure 2. Clinical Signs of Hyperdrainage; Major Depression of the Fontanel with a Tendency to Craniosynostosis (A) and Abdominal Bloating (B)

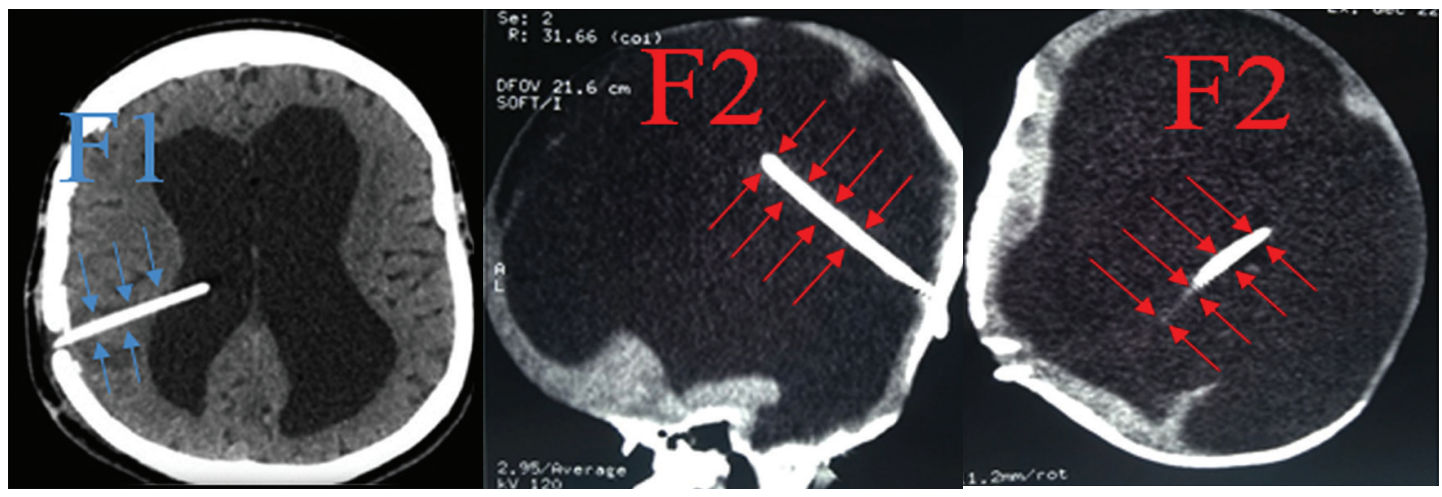

Figure 3. Pressing Forces Exerted by the Cerebral Tissue along the Catheter (F1) Greater Than Those of the Cerebrospinal Fluid (F2) 
tube in one's body, increases with the density of body [36]. Thus, the pressure exerted on the walls of the ventricular catheter by the cerebral tissue is greater than that of the CSF (Figure 3). We, therefore, believe that the absence of brain tissue (which should be a constraint on ventricular catheter along its path and constitutes additional resistance to the flow of the LCS) in hydranencephaly, further exposes them to overdrainage. Furthermore, the presence of a high quantity of CSF in the hydranencephaly predisposes them to this complication. There is no evidence from randomized clinical trials indicating flow-regulated and differential pressure regulated shunt valves difference with regard to clinical outcome, shunt failure, or intervention risks [37]. Thus, it can be concluded that the combination of the two systems through our technique reduces the risk of overdrainage. This method has never been reported in the literature. Although it provides a solution to the problem, the partial ligature of the catheter nevertheless presents, at long term, the risk of hypodrainage or catheter section. The best valves for this type of pathology would be flow-regulated ones.

Overdrainage is one of the complications of the VPS, especially of hydranencephaly in our department. The pressing forces of the cerebral tissue which apply on the ventricular catheter provide additional resistance to the drainage flow of valves in conventional hydrocephalus, unlike hydranencephaly. The ligation of the catheter is an effective technique for treating or preventing overdrainage even if it involves a risk of hypodrainage.

\section{Funding}

None.

\section{Conflicts of interest}

All authors certify that they have no affiliations with or involvement in any organization or entity with any financial interest (such as honoraria; educational grants; participation in speakers' bureaus; membership, employment, consultancies, stock ownership, or other equity interest; and expert testimony or patent-licensing arrangements), or non-financial interest (such as personal or professional relationships, affiliations, knowledge or beliefs) in the subject matter or materials discussed in this manuscript.

\section{Authors' Contribution}

Conception and Design: Essossinam Kpélao

Data Collection: Essossinam Kpélao, Katanga Anthony Békéti, Abdel Kader Moumouni, Kodjo Mensah Hobli Ahanogbé, Agbéko Komlan Doléagbenou, Komi Egu

Drafting the Article: Essossinam Kpélao

Critically Revising the Article: Thierry Alihonou, Essosolim Hodabalo Bakondé, Pilakimwé Egbohou, Assang Dossim

Reviewed Submitted Version of the Manuscript:

Essossinam Kpélao, Thierry Alihonou, Essosolim Hodabalo Bakondé, Pilakimwé Egbohou, Assang Dossim

Approved the Final Version of the Manuscript: Essossinam Kpélao

\section{References}

1. Faulhauer K, Schmitz P. Overdrainage phenomena in shunt treated hydrocephalus. Acta Neurochir. 1978; 45 :89-101.

2. Pudenz RH, Foltz EL. Hydrocephalus: overdrainage by ventricular shunts. A review and recommendations. Surg Neurol. 1991; 35(3): 200-212.

3. Epstein F, Lapras C, Wisoff JH. 'Slit-ventricle syndrome': etiology and treatment. Pediatr Neurosurg. 1988; 14 :5-10.

4. Tschan CA, Antes S, Huthmann A, Vulcu S, Oertel J, Wagner W. Overcoming CSF overdrainage with the adjustable gravitational valve proSA. Acta Neurochir (Wien). 2014; $156: 767-776$.

5. Aschoff A, Kremer P, Benesch C, Fruh K, Klank A, Kunze S. Overdrainage and shunt technology. Childs Nerv Sys. 1995 ;11:193-202.

6. Drake JM, Kestle JR, Milner R, Cinalli G, Boop F, Piatt J $\mathrm{Jr}$, et al. Randomized trial of cerebrospinal fluid shunt valve design in pediatric hydrocephalus. Neurosurg. 1998; 43 :294 303.

7. Portnoy HD, Schulte RR, Fox JL, Croissant PD, Tripp L. Antisiphon and reversible occlusion valves for shunting in hydrocephalus and preventing post-shunt subdural hematomas. J Neurosurg. 1973; 38(6):729-738.

8. Reinprecht A, Dietrich W, Bertalanffy A, Czech T. The Medos Hakim programmable valve in the treatment of pediatric hydrocephalus. Childs Nerv Sys. 1997; 13(11-12) :588-593.

9. Piatt JH, Carlson CV. A search for determinants of cerebrospinal fluid shunt survival: Retrospective analysis of a 14 years institutional experience. Pediatr. Neurosurg. 1993; 19 (5): 233-241

10. Sainte-Rose C, Piatt JH, Renier D, Pierre-Kahn A, Hirsch JF, Hoffman HJ, et al. Mechanical complications in shunts. Pediatr. Neurosurg. 1991-1992; 17 (1): 2-9.

11. Freimann FB, Sprung C. Shunting with gravitational valves-can adjustments end the era of revisions for overdrainage-related events? J Neurosurg. 2012; 117 :11971204

12. Boon AJ, Tans JT, Delwel EJ, Egeler-Peerdeman SM, Hanlo PW,Wurzer HA, et al. Dutch Normal-PressureHydrocephalus Study. Randomized comparison of low- and medium-pressure shunts. J Neurosurg. 1998; 88(3) :490-495. 13. Gruber RW, Roehrig B. Prevention of ventricular catheter obstruction and slit ventricle syndrome by the prophylactic use of the Integra antisiphon device in shunt therapy for pediatric hypertensive hydrocephalus: a 25-year follow-up study. J Neurosurg Pediatr. 2010; 5(1):4-16. 
14. Kestle J, Drake J, Milner R, Sainte-Rose C, Cinalli G, Boop F, et al. Longterm follow-up data from the Shunt Design Trial. Pediatr Neurosurg. 2000; 33(5) :230-236.

15. Freimann FB, Kimura T, Stockhammer F, Schulz M, Rohde V, Thomale UW. In vitro performance and principles of antisiphoning devices. Acta Neurochir (Wien). 2014; 156 2191-2199.

16. Drake JM, Tenti G, Sivalsganathan S. Computer modeling of siphoning for CSF shunt design evaluation. Pediatr Neurosurg. 1994; $21: 6-15$.

17. Cheok S, Chen J, Lazareff J. The truth and coherence behind the concept of overdrainage of cerebrospinal fluid in hydrocephalic patients. Childs Nerv Syst. 2014; 30(4) :599606.

18. Fox JL, McCullough DC, Green RC. Effect of cerebrospinal fluid shunts on intracranial pressure and on cerebrospinal fluid dynamics 2. A new technique of pressure measurements: results and concepts 3 . A concept of hydrocephalus. J Neurol Neurosurg Psychiatry. 1973; $36: 302-312$.

19. Meier U, Stengel D, Müller C, Fritsch MJ, Kehler U, Langer $\mathrm{N}$, et al. Predictors of subsequent overdrainage and clinical outcomes after ventriculoperitoneal shunting for idiopathic normal pressure hydrocephalus. Neurosurgery. 2013; 73 :1054-1060.

20. Diesner N, Freimann F, Clajus C, Kallenberg K, Rohde V, Stockhammer F. Female gender predisposes for cerebrospinal fluid overdrainage in ventriculoperitoneal shunting. Acta Neurochir. 2016; 158 (7) :1273-8.

21. Enzi G, Gasparo M, Biondetti PR, Fiore D, Semisa M, Zurlo F. Subcutaneous and visceral fat distribution according to sex, age, and overweight, evaluated by computed tomography. Am J Clin Nutr.1986; 44 :739-746.

22. Yamada H, Tajima M, Nagaya M. Effect of respiratory movement on cerebrospinal fluid dynamics in hydrocephalic infants with shunts. J Neurosurg. 1975; 42(2) :194-200.

23. Andersson H. Craniosynostosis as a complication after operation for hydrocephalus. Acta Paediatr. 1966; 55 :192196.

24. Czosnyka M, Czosnyka Z, Pickard JD. Programmable shunt assistant tested in Cambridge shunt evaluation laboratory. Acta Neurochir (Wein). 2012; 113 :71-76.

25. Kehler U, Kiefer M, Eymann R, Wagner W, Tschan CA, Langer N, et al. PROSAIKA: a prospective multicenter registry with the first programmable gravitational device for hydrocephalus shunting. Clin Neurol Neurosurg. 2015; 137: $132-136$.

26. Kay AD, Fisher AJ, O'Kane C, Richards HK, Pickard JD. A clinical audit of the Hakim programmable valve in patients with complex hydrocephalus. Br J Neurosurg. 2000; 14(6) :535-543.

27. Kiefer M. Treatment of hydrocephalus. Radiologe. 2012; $52(9): 833-839$

28. Kremer P, Aschoff A, Kunze S. Risks of using siphonreducing devices. Childs Nerv Syst. 1994; 10(4) :231235.

29. Covington C, Taylor H, Gill C, Padaliya B, Newman W, Smart JR 3rd, et al. Prolonged survival in hydranencephaly: a case report. Tenn Med. 2003; 96(9) :423-4.

30. Cecchetto G, Milanese L, Giordano R, Viero A, Suma V, Manara R. Looking at the missing brain: hydranencephaly case series and literature review. Pediatr Neurol. 2013; 48(2) :152-8

31. Sutton LN, Bruce DA, Schut L. Hydranencephaly versus maximal hydrocephalus: an important clinical distinction. Neurosurgery. 1980; 6(1) :34-8.

32. Adeloye A. Hydranencephaly in Malawian children. East Afr Med J. 2000; 77(6): 316-8.

33. Malheiros JA, Trivelato FP, Oliveira MM, Gusmão S, Cochrane DD, Steinbok P. Endoscopic choroid plexus cauterization versus ventriculoperitoneal shunt for hydranencephaly and near hydranencephaly: a prospective study. Neurosurgery. 2010; 66(3): 459-64.

34. Hode L, Gandaho HJP, Yekpe FP, Alihonou T, Houessou
GF, Hadonou AA, et al. Hydranencephalie a cotonou (benin) a propos de 3 cas cliniques. African Journal of Neurological Sciences. 2013; 32 (2): 65-71

35. Hyde-Rowan MD, Rekate HL, Nulsen FE. Reexpansion of previously collapsed ventricles: the slit ventricle syndrome. J Neurosurg. 1982; $56: 536-9$.

36. Thomas PF, Azan JL. Calcul des forces pressantes sur les parois planes. In : Thomas PF, Azan JL (eds) Précis de physique-chimie. Bréal, Nanterre: Levallois-Perret. 2006; 171-173.

37. Ziebell M, Wetterslev J, Tisell M, Gluud C, Juhler M. Flow-regulated versus differential pressure-regulated shunt valves for adult patients with normal pressure hydrocephalus. Cochrane Database Syst Rev. 2013; 31 (5):CD009706. doi: 10.1002/14651858.CD009706.pub2. 